\title{
Erratum to: Ultrastructure of interstitial cells of Cajal in myenteric plexus of human colon
}

Jüri Johannes Rumessen • Jean-Marie Vanderwinden • Helle Rasmussen • Alastair Hansen • Thomas Horn

Published online: 23 October 2009

Erratum to: Cell Tissue Res

DOI 10.1007/s00441-009-0818-6

The correct author list is given here.

The online version of the original article can be found at http://dx.doi. org/10.1007/s00441-009-0818-6.

J. J. Rumessen $(\bowtie)$

Department of Gastroenterology F, Gentofte Hospital,

Niels Andersensvej 65,

DK-2900 Hellerup, Denmark

e-mail: juru@geh.regionh.dk

J.-M. Vanderwinden

Faculté de Médecine, Université Libre de Bruxelles,

Brussels, Belgium

e-mail: jmvdwin@ulb.ac.be

H. Rasmussen

Department of Pathology, University Hospital Herlev,

DK-2730 Herlev, Denmark

e-mail: hellera6@yahoo.com

A. Hansen · T. Horn

Department of Pathology, University Hospital Herlev

and University of Copenhagen,

DK-2730 Herlev, Denmark
A. Hansen
e-mail: alahan01@heh.regionh.dk
T. Horn
e-mail: thoho@heh.regionh.dk 